\title{
Reclassification of the members of the genus Tetrathiobacter Ghosh et al. 2005 to the genus Advenella Coenye et al. 2005
}

\author{
Correspondence \\ J. F. Fernández-Garayzábal \\ garayzab@vet.ucm.es
}

\author{
A. Gibello, ${ }^{1}$ A. I. Vela, ${ }^{1,2}$ M. Martín, ${ }^{3}$ A. Barra-Caracciolo, ${ }^{4}$ P. Grenni ${ }^{4}$ \\ and J. F. Fernández-Garayzábal ${ }^{1,2}$
${ }^{1}$ Dpto Sanidad Animal, Facultad de Veterinaria, Universidad Complutense, 28040 Madrid, Spain
${ }^{2}$ Centro de Vigilancia Sanitaria Veterinaria (VISAVET), Facultad de Veterinaria, Universidad Complutense, 28040 Madrid, Spain
${ }^{3}$ Dpto Bioquímica y Biología Molecular IV, Facultad de Veterinaria, Universidad Complutense, 28040 Madrid, Spain
${ }^{4}$ Water Research Institute - National Research Council, Via Reno 1, 00198 Rome, Italy

\begin{abstract}
The taxonomic position of the genera Advenella and Tetrathiobacter was examined. 16S rRNA gene sequence analysis revealed that the two genera are closely related, representing a monophyletic cluster with high sequence similarity (98.1-99.7\%) within the family Alcaligenaceae. The phenotypic characteristics of the type strains of Advenella incenata, Tetrathiobacter kashmirensis and Tetrathiobacter mimigardefordensis were re-examined using the API 20NE, API ZYM and API 50CH systems. Phylogenetic data together with similarities in phenotypic characteristics, $\mathrm{G}+\mathrm{C}$ content and cellular acid composition suggest that they should be classified in the same genus. On the basis of the data presented, the two species of the genus Tetrathiobacter should be transferred to the genus Advenella, since this genus has nomenclatural priority. Therefore, Tetrathiobacter kashmirensis and Tetrathiobacter mimigardefordensis should be transferred to the genus Advenella as Advenella kashmirensis comb. nov. (type strain WT001 ${ }^{\top}$

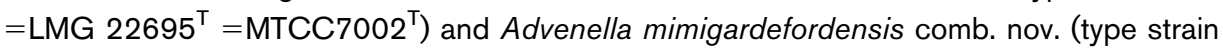


genus Advenella are also presented.
\end{abstract}

In the course of a study of environmental bacteria able to use n-triazines, we isolated several strains from groundwater contaminated by terbutylazine. Preliminary phylogenetic analysis of the 16S rRNA gene sequences of these strains (about $700 \mathrm{nt}$ ) revealed that their closest relatives were members of the genera Advenella and Tetrathiobacter. The genus Advenella was proposed by Coenye et al. (2005) to accommodate Gram-negative, rod-shaped to coccoid, oxidase-positive bacteria isolated from various human and veterinary clinical samples. Advenella incenata is the type and single species of this genus. The genus Tetrathiobacter, with the type species Tetrathiobacter kashmirensis, was created by Ghosh et al. (2005) to describe Gram-negative, non-flagellated, oval to coccoid-shaped bacteria occurring singly or in pairs, chains, branched chains or clusters isolated from bulk soils of a temperate orchard in Srinagar, Jammu and Kashmir, India. Another species, Tetrathio-

The GenBank/EMBL/DDBJ accession numbers for the 16S rRNA gene sequences of $A$. incenata strains CCUG $45225^{\top}$ and $4 \mathrm{GA}-2008$ are AM944734 and AM944735. bacter mimigardefordensis, was described soon after by Wübbeler et al. (2006). Both genera are members of the family Alcaligenaceae (De Ley et al., 1986). In this study, we present the results of the phenotypic and phylogenetic characterization of the environmental bacterial isolates and a critical taxonomic evaluation of the members of the two genera, and propose the combination of the genus Tetrathiobacter with the genus Advenella, since the latter has nomenclatural priority.

The environmental isolates 4GA-2008, 6GA-2008 and 7GA-2008 were isolated from groundwater contaminated by terbutylazine, located in Assisi, in central Italy. Primary isolation was achieved on minimal medium (MM) $\left[1^{-1}\right.$; $1.6 \mathrm{~g} \mathrm{~K}_{2} \mathrm{HPO}_{4}, 0.4 \mathrm{~g} \mathrm{KH} \mathrm{KO}_{4}, 0.1 \mathrm{~g} \mathrm{CaSO}_{4} \cdot 2 \mathrm{H}_{2} \mathrm{O}, 1 \mathrm{~g}$ $\mathrm{MgSO}_{4} \cdot 7 \mathrm{H}_{2} \mathrm{O}, 0.02 \mathrm{~g} \mathrm{FeSO}_{4} \cdot 7 \mathrm{H}_{2} \mathrm{O}, 2 \mathrm{~g}\left(\mathrm{NH}_{4}\right)_{2} \mathrm{SO}_{4}, 15 \mathrm{~g}$ agar], supplemented with 2 p.p.m. terbutylazine and $0.03 \%$ Casamino acids, after incubation at $30{ }^{\circ} \mathrm{C}$ for $48 \mathrm{~h}$ under aerobic conditions. After primary isolation and further subculture on Luria-Bertani (LB) agar plates at $30{ }^{\circ} \mathrm{C}$ for $48 \mathrm{~h}$, isolates were stored at $-20{ }^{\circ} \mathrm{C}$ as glycerol suspensions $(20 \% \mathrm{v} / \mathrm{v})$. A. incenata CCUG $45225^{\mathrm{T}}, T$. 
kashmirensis LMG $22695^{\mathrm{T}}$ and LMG 22696 and $T$. mimigardefordensis LMG $22922^{\mathrm{T}}$ were obtained from the respective culture collections, grown aerobically at $30{ }^{\circ} \mathrm{C}$ on LB agar plates for $48 \mathrm{~h}$ and stored at $-20{ }^{\circ} \mathrm{C}$ as glycerol suspensions $(20 \% \mathrm{v} / \mathrm{v})$.

Phylogenetic analysis of the environmental isolates was performed by comparative 16S rRNA gene sequence analysis as described previously (Vela et al., 2006). The sequence of a large fragment of the 16S rRNA gene of the three isolates (approx. 1440 bases) as well as that of $A$. incenata CCUG $45225^{\mathrm{T}}$ (1341 bp; the sequence available previously in GenBank had only 734 nucleotides) was obtained bidirectionally. 16S rRNA gene sequence analysis revealed $100 \%$ similarity among the three environmental strains. Sequence searches of GenBank using the program FASTA (Pearson, 1994) confirmed the preliminary sequencing results and confirmed that the environmental isolates were phylogenetically most closely related to $T$. kashmirensis $\mathrm{WT}^{0} \mathrm{1}^{\mathrm{T}}$ (99.7\% sequence similarity), A. incenata CCUG $45225^{\mathrm{T}}$ (99.4\% to the new, longer sequence) and $T$. mimigardefordensis $\mathrm{DPN}^{\mathrm{T}}$ (99.0\%). These sequences and those of other representative members of the family Alcaligenaceae were retrieved from GenBank and aligned with the newly determined sequence by using the program DNATools (Rasmussen, 1995). Phylogenetic trees were constructed according to three different methods, a neighbour-joining algorithm (Saitou \& Nei, 1987), per- formed with the programs DNATools and TreeView (Page, 1996), maximum-likelihood analysis done using the PHYML software (Guindon \& Gascuel, 2003) and maximumparsimony method carried out using the MEGA software package version 3.1 (Kumar et al., 2004). Genetic distances for the neighbour-joining and maximum-likelihood algorithms were calculated by Kimura's two-parameter model (Kimura, 1980) and close-neighbour interchange (search level $=2$, random additions $=100$ ) was applied in maximumparsimony analysis. The stability of the groupings was estimated by bootstrap analysis (1000 replications). The members of the genera Advenella and Tetrathiobacter formed a monophyletic cluster with $100 \%$ bootstrap support and were readily differentiated from other genera of the family Alcaligenaceae (Fig. 1). Within this cluster, T. mimigardefordensis $\mathrm{DPN}^{\mathrm{T}}$ formed a distinct subline from that formed by A. incenata CCUG $45225^{\mathrm{T}}$ and T. kashmirensis WT001 ${ }^{\mathrm{T}}$ with $99 \%$ bootstrap support. This tree topology was confirmed by the three phylogenetic algorithms. Pairwise $16 \mathrm{~S}$ rRNA gene sequence similarity values within this cluster ranged between 98.1 and $99.7 \%$; these values are typical of members of the same genus. The $\mathrm{G}+\mathrm{C}$ contents of members of the genera Advenella (53.5-58.0 mol\%) and Tetrathiobacter (54.0-55.2 mol\%) and their cellular fatty acid compositions, with $16: 0$ and $18: 1 \omega 7 c$ as the predominant fatty acids, are very similar (Coenye et al., 2005; Ghosh et al., 2005; Wübbeler et al., 2006).

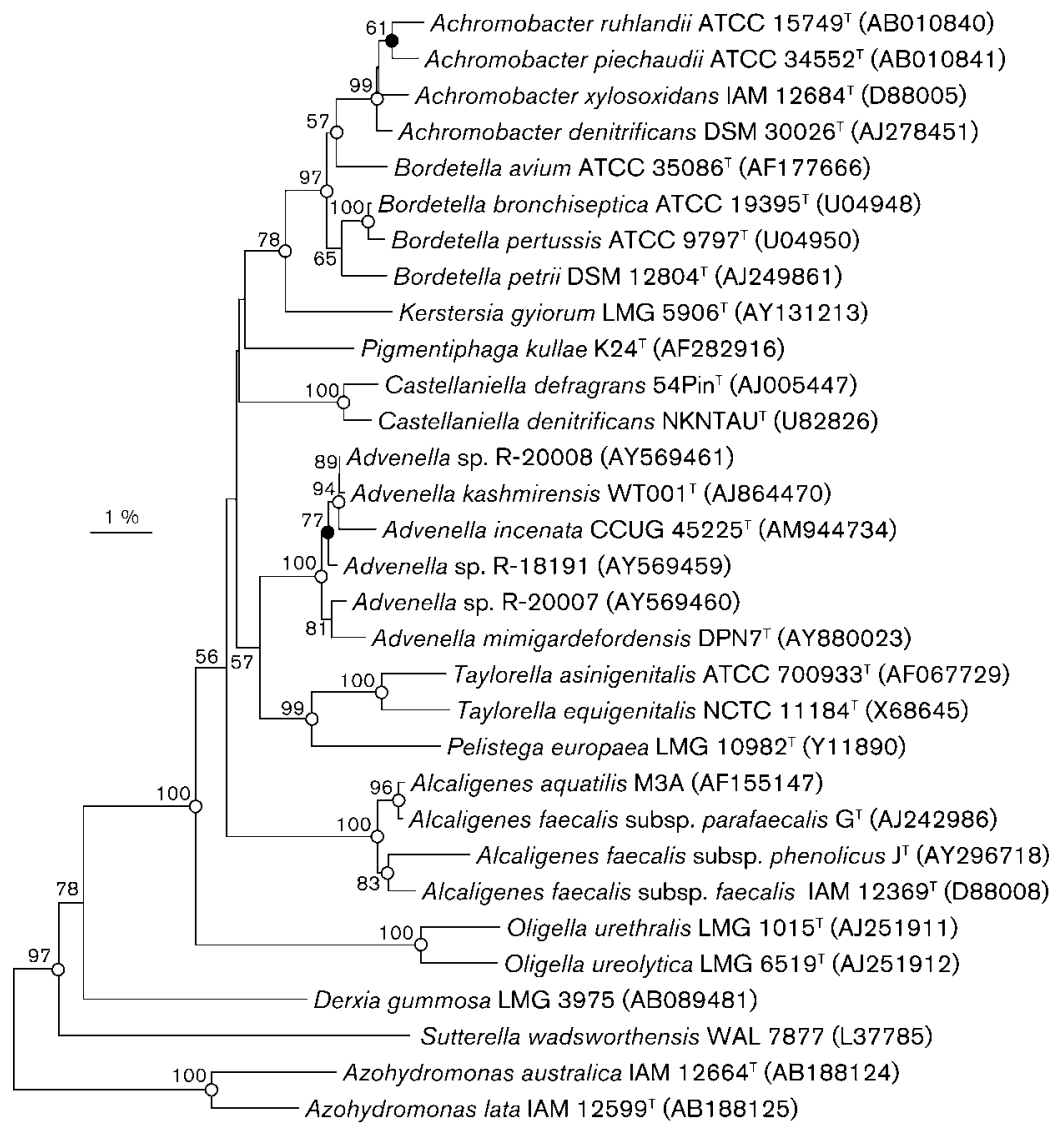

Fig. 1. Phylogenetic tree inferred from $16 \mathrm{~S}$ rRNA gene sequence comparison using the neighbour-joining method, showing the relationships of the members of the genus Advenella with other taxa of the family Alcaligenaceae. The sequence of Zoogloea ramigera ATCC 19324 (GenBank accession no. D14257) was used as an outgroup (not shown). Bootstrap values (expressed as percentages of 1000 replications) higher than $50 \%$ are given at branching points. Filled circles indicate that the corresponding nodes (groupings) were also obtained in maximumlikelihood trees. Open circles indicate that the corresponding nodes (groupings) were also obtained in maximum-likelihood and parsimony trees. Bar, $1 \%$ sequence divergence. 
The phenotypic characteristics described for A. incenata, $T$. kashmirensis and T. mimigardefordensis are not directly comparable, because the same characteristics were not determined for the three species (Coenye et al., 2005; Ghosh et al., 2005; Wübbeler et al., 2006). In this study, the environmental isolates were characterized phenotypically and the phenotypic characteristics of $A$. incenata CCUG $45225^{\mathrm{T}}$, T. kashmirensis LMG $22695^{\mathrm{T}}$ and T. mimigardefordensis LMG $22922^{\mathrm{T}}$ were re-examined using commercial kits. Biochemical and enzyme characteristics were determined using the API 20NE and API ZYM systems (bioMérieux) according to the manufacturer's instructions. Carbohydrate assimilation was essayed by using API $50 \mathrm{CH}$ strips (bioMérieux) which were inoculated with a 0.5 McFarland suspension of bacterial cells in AUX medium (bioMérieux). The API $50 \mathrm{CH}$ strips were read for up to 4 days of incubation at $30{ }^{\circ} \mathrm{C}$. Assimilation of DL-lactate was determined in MM broth containing $1 \%(w / v)$ DLlactate (Sigma). The environmental isolates exhibited almost identical phenotypic characteristics, which matched those exhibited by A. incenata CCUG $45225^{\mathrm{T}}$ except that they did not hydrolyse urea (A. incenata CCUG $45225^{\mathrm{T}}$ was positive). A. incenata CCUG $45225^{\mathrm{T}}$, T. kashmirensis LMG $22695^{\mathrm{T}}$ and T. mimigardefordensis LMG $22922^{\mathrm{T}}$ also exhibited many common characteristics, although several tests can be used for their differentiation. The results are given in the species descriptions and in Table 1.

The distinct phylogenetic position of T. mimigardefordensis and its separate species status with respect to T. kashmirensis were supported by DNA-DNA hybridization experiments and by differences in biochemical and chemotaxonomic characteristics (Wübbeler et al., 2006). Therefore, genomic relatedness was examined to determine the species status of the environmental strains with respect to A. incenata and $T$. kashmirensis and between $A$. incenata and both species of Tetrathiobacter. DNA-DNA hybridization experiments were carried out between isolate 4GA-2008 and isolates 6GA-2008 and 7GA-2008, between isolate 4GA-2008 and its nearest

Table 1. Phenotypic characteristics that differentiate type strains of the genus Advenella

Strains: 1 , A. incenata CCUG $45225^{\mathrm{T}}$; 2, A. kashmirensis comb. nov. LMG $22695^{\mathrm{T}}$; 3, A. mimigardefordensis comb. nov. LMG $22922^{\mathrm{T}}$. Data were obtained in this study.

\begin{tabular}{|lccc|}
\hline Characteristic & $\mathbf{1}$ & $\mathbf{2}$ & $\mathbf{3}$ \\
\hline Nitrate reduction & - & + & - \\
Assimilation of: & & & \\
$\quad$ Glycerol & + & - & + \\
L-Rhamnose & + & + & - \\
D-Fructose & - & + & - \\
Melezitose & - & - & + \\
2-Ketogluconate & + & - & - \\
DL-Lactate & + & - & + \\
Esterase (C4) activity & + & + & - \\
\hline
\end{tabular}

phylogenetic neighbours A. incenata CCUG $45225^{\mathrm{T}}$ and $T$. kashmirensis LMG $22695^{\mathrm{T}}$, between the two latter strains and between $A$. incenata CCUG $45225^{\mathrm{T}}$ and T. kashmirensis LMG 22696 and T. mimigardefordensis LMG $22922^{\mathrm{T}}$. DNA was isolated using a French pressure cell (Thermo Spectronic) and purified by chromatography on hydroxyapatite as described by Cashion et al. (1977). DNA-DNA hybridization was carried out as described by De Ley et al. (1970) under consideration of the modifications described by Huß et al. (1983) using a Cary 100 Bio UV/Vis spectrophotometer equipped with a Peltier-thermostatted $6 \times 6$ multicell changer and a temperature controller with in situ temperature probe (Varian). Preparation of high-molecular-mass DNA and DNA-DNA hybridization experiments were performed by the DSMZ Identification Service (Braunschweig, Germany). DNA-DNA hybridization between isolate 4GA-2008 and isolates 6GA-2008 and 7GA-2008 showed DNA relatedness values of 95.1 and $84.9 \%$, respectively. The DNA-DNA reassociation values between isolate 4GA-2008 and $A$. incenata CCUG $45225^{\mathrm{T}}$, T. kashmirensis LMG $22695^{\mathrm{T}}$ and T. kashmirensis LMG 22696 were 93.9, 44.8 and $31.4 \%$, respectively, demonstrating that the environmental isolates are members of the species A. incenata (Wayne et al., 1987). DNA-DNA reassociation values between $A$. incenata CCUG $45225^{\mathrm{T}}$ and T. kashmirensis LMG $22695^{\mathrm{T}}$, T. kashmirensis LMG 22696 and T. mimigardefordensis LMG $22922^{\mathrm{T}}$ were $48.3,44.0$ and $27.7 \%$, respectively. These values are below the recommended threshold value of $70 \%$, confirming that they merit their separate species status (Wayne et al., 1987).

Considering the phenotypic similarities, phylogenetic position and genetic and chemotaxonomic data, $A$. incenata, T. kashmirensis and T. mimigardefordensis should be members of the same genus. The names Advenella and Tetrathiobacter were published in the same year but, according to the Bacteriological Code (Rule 24b), the genus Advenella has priority and, consequently, the two species of the genus Tetrathiobacter should be reclassified as members of the genus Advenella.

\section{Emended description of the genus Advenella Coenye et al. 2005}

Advenella (Ad.ven.el'la. L. n. advena a stranger, a foreigner; L. dim. ending -ella; N.L. fem. n. Advenella the little stranger, referring to the fact that the source of the first strains was unknown).

The description is as given by Coenye et al. (2005) with the following modifications. Some members of the genus do not assimilate DL-lactate, D-mannose or maltose. The type species is Advenella incenata.

\section{Emended description of Advenella incenata Coenye et al. 2005}

Advenella incenata (in.ce.na'ta. L. fem. adj. incenata that has not dined, fasting, referring to the fact that this organism shows little biochemical activity). 
The description remains that given by Coenye et al. (2005) with the following additions. Assimilates adipate, glycerol, D- and L-xylose, D-arabinose, galactose, ribose, rhamnose, D- and L-fucose, gluconate and 2-ketogluconate, but does not assimilate erythritol, D-adonitol, turanose, tagatose, Dlyxose, xylitol, gentiobiose, glycogen, sucrose, melibiose, D- or L-arabitol, methyl $\beta$-D-glucopyranoside, methyl $\alpha$-Dmannopyranoside, sorbitol, starch, raffinose, inulin, dulcitol, inositol, L-sorbose, methyl $\beta$-D-xylopyranoside, Dfructose, trehalose or melezitose.

The type strain is CCUG $45225^{\mathrm{T}}=\mathrm{LMG} 22250^{\mathrm{T}}$, isolated from human sputum in Sweden.

\section{Description of Advenella kashmirensis comb. nov.}

Advenella kashmirensis (kash.mir.en'sis. N.L. masc. adj. kashmirensis of Kashmir, after the name of the province from where the original strains of the species were isolated).

Basonym: Tetrathiobacter kashmirensis Ghosh et al. 2005.

The description is as given for Tetrathiobacter kashmirensis by Ghosh et al. (2005) with the following additions or modifications. Assimilates adipate, D- and L-xylose, Darabinose, galactose, ribose, rhamnose, D- and L-fucose, gluconate and fructose, but does not assimilate erythritol, D-adonitol, turanose, tagatose, D-lyxose, xylitol, gentiobiose, glycogen, sucrose, melibiose, D- or L-arabitol, methyl $\beta$-D-glucopyranoside, methyl $\alpha$-D-mannopyranoside, sorbitol, starch, raffinose, inulin, dulcitol, inositol, L-sorbose, methyl $\beta$-D-xylopyranoside, glycerol, trehalose, 2-ketogluconate or melezitose. Esterase (C4), acid phosphatase (weak reaction) and alkaline phosphatase activities are detected. No activity is detected for esterase lipase (C8) and cystine arylamidase.

The type strain is $\mathrm{WT}_{001}^{\mathrm{T}} \quad\left(=\mathrm{LMG} \quad 22695^{\mathrm{T}}\right.$ $=$ MTCC $7002^{\mathrm{T}}$ ), isolated from bulk soil of a temperate orchard in Srinagar, Jammu and Kashmir, India.

\section{Description of Advenella mimigardefordensis comb. nov.}

Advenella mimigardefordensis (mi.mi.gar.de.for.den'sis. M.L. masc. adj. mimigardefordensis of Mimegardefordum, a medieval name of Münster, where the type strain was isolated).

Basonym: Tetrathiobacter mimigardefordensis Wübbeler et al. 2006.

The description remains that given for Tetrathiobacter mimigardefordensis by Wübbeler et al. (2006) with the following additions. Assimilates glycerol, DL-lactate, adipate, D- and L-xylose, D-arabinose, D-galactose, ribose, Dand L-fucose, gluconate and melezitose, but does not assimilate erythritol, D-adonitol, turanose, tagatose, Dlyxose, xylitol, gentiobiose, glycogen, sucrose, melibiose, starch, D- or L-arabitol, methyl $\beta$-D-glucopyranoside, methyl $\alpha$-D-mannopyranoside, sorbitol, raffinose, inulin, dulcitol, inositol, L-sorbose, methyl $\beta$-D-xylopyranoside, Dfructose, D-rhamnose, trehalose or 2-ketogluconate. Alkaline phosphatase (weak reaction), acid phosphatase and esterase lipase (C8) are detected. No activity is detected for esterase (C4) or cystine arylamidase.

The type strain is DPN7 ${ }^{\mathrm{T}}\left(=\mathrm{DSM} 17166^{\mathrm{T}}=\mathrm{LMG} 22922^{\mathrm{T}}\right)$, isolated from a sample of matured compost from a compost plant in Münster (Germany).

\section{Acknowledgements}

The authors thank A. Casamayor for technical assistance and Juncal Fernández-Garayzábal for her assistance with the English reviewing of the manuscript. This work was funded by project CTM-2007-66306C02-01 of the Spanish Ministry of Education and Science.

\section{References}

Cashion, P., Holder-Franklin, M. A., McCully, J. \& Franklin, M. (1977). A rapid method for the base ratio determination of bacterial DNA. Anal Biochem 81, 461-466.

Coenye, T., Vallaere, E., Samyn, E., Falsen, E., Larsson, P. \& Vandamme, P. (2005). Advenella incenata gen. nov., sp. nov., a novel member of the Alcaligenaceae, isolated from various clinical samples. Int J Syst Evol Microbiol 55, 251-256.

De Ley, J., Cattoir, H. \& Reynaerts, A. (1970). The quantitative measurement of DNA hybridization from renaturation rates. Eur J Biochem 12, 133-142.

De Ley, J., Segers, P., Kersters, K., Mannheim, W. \& Lievens, A. (1986). Intra- and intergeneric similarities of the Bordetella ribosomal ribonucleic acid cistrons: proposal for a new family, Alcaligenaceae. Int J Syst Bacteriol 36, 405-414.

Ghosh, W., Bagchi, A., Mandal, S., Dam, B. \& Roy, P. (2005). Tetrathiobacter kashmirensis gen. nov., sp. nov., a novel mesophilic, neutrophilic, tetrathionate-oxidizing, facultatively chemolithotrophic betaproteobacterium isolated from soil from a temperate orchard in Jammu and Kashmir, India. Int J Syst Evol Microbiol 55, 1779-1787.

Guindon, S. \& Gascuel, O. (2003). A simple, fast, and accurate algorithm to estimate large phylogenies by maximum likelihood. Syst Biol 52, 696-704.

Huß, V. A. R., Festl, H. \& Schleifer, K. H. (1983). Studies on the spectrophotometric determination of DNA hybridization from renaturation rates. Syst Appl Microbiol 4, 184-192.

Kimura, M. (1980). A simple method for estimating evolutionary rates of base substitutions through comparative studies of nucleotide sequences. J Mol Evol 16, 111-120.

Kumar, S., Tamura, K. \& Nei, M. (2004). MEGA3: integrated software for molecular evolutionary genetics analysis and sequence alignment. Brief Bioinform 5, 150-163.

Page, R. D. M. (1996). TREEVIEW: an application to display phylogenetic trees on personal computers. Comput Appl Biosci 12, 357-358.

Pearson, W. R. (1994). Using the FASTA program to search protein and DNA sequence databases. Methods Mol Biol 24, 307-331.

Rasmussen, S. W. (1995). DNATools, a software package for DNA sequence analysis. Copenhagen: Carlsberg Laboratory. 
Saitou, N. \& Nei, M. (1987). The neighbor-joining method: a new method for reconstructing phylogenetic trees. Mol Biol Evol 4, 406-425.

Vela, A. I., Gutiérrez, M. C., Falsen, E., Rollan, E., Simarro, I., García, P., Domínguez, L., Ventosa, A. \& Fernández-Garayzábal, J. F. (2006). Pseudomonas simiae sp. nov., isolated from clinical specimens from monkeys (Callithrix geoffroyi). Int J Syst Evol Microbiol 56, 2671-2676.

Wayne, L. G., Brenner, D. J., Colwell, R. R., Grimont, P. A. D., Kandler, O., Krichevsky, M. I., Moore, L. H., Moore, W. E. C., Murray, R. G. E. \& other authors (1987). International Committee on Systematic Bacteriology. Report of the ad hoc committee on reconciliation of approaches to bacterial systematics. Int J Syst Bacteriol 37, 463-464.

Wübbeler, J. H., Lütke-Eversloh, T., Van Trappen, S., Vandamme, P. \& Steinbüchel, A. (2006). Tetrathiobacter mimigardefordensis sp. nov., isolated from compost, a betaproteobacterium capable of utilizing the organic disulfide 3,3' -dithiodipropionic acid. Int J Syst Evol Microbiol 56, 1305-1310. 